\title{
Limpograss (Hemarthria altissima) Overview and Management ${ }^{1}$
}

\section{Yoana Newman, Joao Vendramini, Lynn E. Sollenberger, and Ken Quesenberry ${ }^{2}$}

Limpograss is a warm-season perennial grass used by Florida beef cattle producers because of its high quality, cool-season growth and tolerance of poorly drained soils.

This grass is well adapted to flatwoods sites in Florida and to similar areas characterized by a flat to gently-sloping topography and poorly drained, sandy soils, where standing water is common during wet weather. Limpograss should not be planted on high grounds or deep sands.

Limpograss is one of the first grasses to initiate growth after a cool winter. In fall and early spring, this grass will produce more biomass than other warm-season grasses, especially in South Florida. Because of active growth in late fall, high digestibility and the slower decline with increasing maturity compared to other grasses, limpograss is suitable for use as a stockpiled forage.

Despite high digestibility, however, protein concentration is generally low in limpograss, so protein supplementation is needed to meet the requirements of most livestock that are fed limpograss.

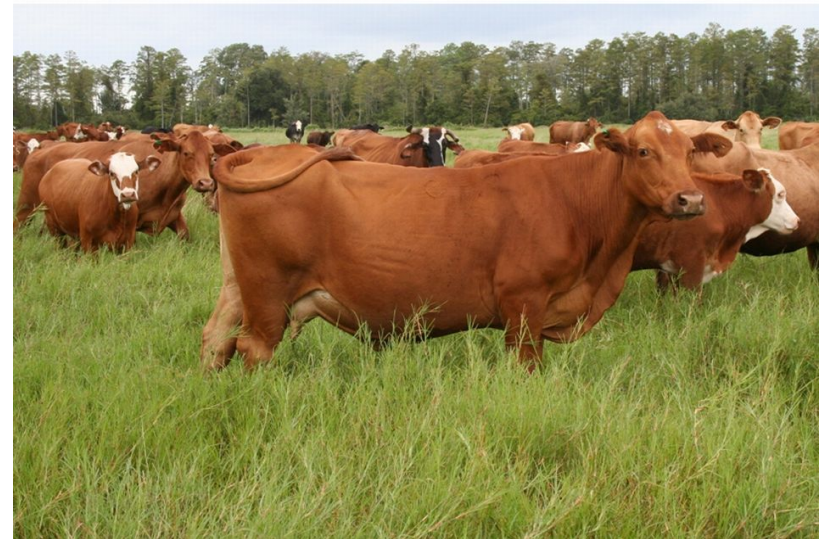

Figure 1. Cattle in a Limpograss Pasture in Florida. Credits: Yoana Newman, IFAS/UF.

\section{History and Released Cultivars}

Limpograss was first introduced in Florida in 1964. Since then evaluations have been conducted at the University of Florida (UF) in Gainesville, as well as at the U.S. Department of Agriculture's Natural Resources Conservation Service (USDA-NRCS) Plant Materials Center at Arcadia, Fla., and at the UF Range Cattle Research and Education Center (REC) at Ona, Fla. As a result of these evaluations, four limpograss cultivars have been released in Florida.

1. This document is SSAGR320, one of a series of the Agronomy Department, Florida Cooperative Extension Service, Institute of Food and Agricultural Sciences, University of Florida. Original publication date, August 2009. Visit the EDIS Web site at http://edis.ifas.ufl.edu.

2. Yoana Newman, assistant professor, Agronomy Department; Joao Vendramini, assistant professor, Agronomy Department, Range Cattle Research and Education Center--Ona, FL; Lynn E. Sollenberger, professor, Agronomy Department, and Ken Quesenberry, professor, Agronomy Department, Institute of Food and Agricultural Sciences, University of Florida, Gainesville, FL. 
These cultivars include the diploids 'Redalta' and

'Greenalta' and the tetraploids 'Bigalta' and 'Floralta'.

Floralta is the most recent release. Redalta and Greenalta were the first releases, but they are no longer recommended because of their low digestibility. Although Redalta is the most cold-tolerant of the four released cultivars, few Redalta pasures are in existence today. Bigalta, the least cold-tolerant of these cultivars, performs best in alternating wet/dry soil conditions. Under grazing conditions, however, Floralta is more persistent than Bigalta, and Bigalta is recommended for use under mechanical defoliation or light grazing.

Ongoing efforts for limpograss improvement continue, and experimental lines are currently being evaluated throughout Florida. About 50 limpograss hybrids were produced by crossing Floralta and Bigalta at UF in Gainesville. These hybrids have undergone evaluation for yield and persistence under clipping defoliation for two years at the UF Range Cattle REC in Ona and at UF in Gainesville and for one year at the UF North Florida REC in Marianna, Fla.

Select lines have shown persistence similar to Floralta, and a second-stage evaluation experiment is in progress. The goal of this breeding effort is to produce a limpograss cultivar with equal or better persistence of Floralta and possible improvement in nutritive value.

Why has Floralta been adopted as the limpograss cultivar for use in Florida? Floralta is recommended over the other limpograss cultivars for use in Florida because of its persistence under grazing, its winter hardiness, high yield, extended grazing season, and high digestibility.

\section{Yield}

Limpograss is most productive during the warmer months, but also has active growth periods in early spring and late fall. Under good fertility and moisture conditions, limpograss produces 8 - 10 tons of hay per acre. In South Florida during mild winters, limpograss continues to grow throughout the cool season, producing 30 - 35 percent of the growth between November and March, compared to 10 - 15 percent for bahiagrass (see Table 1).

Under grazing, limpograss forage mass is variable and increases with increasing grazing height. For example, grazing to a stubble height of 8 inches allows for a grazing-forage mass of 2,500 - 2,800 $\mathrm{lb} /$ acre. When limpograss is grazed to a 16-inch stubble, the forage mass available is approximately 4000 - $4500 \mathrm{lb} / \mathrm{acre}$.

\section{Nutritive Value}

In addition to limpograss' cool-season production, digestibility is considered high relative to other summer grasses (Table 1), ranging from 40 -to 70 percent. Also unlike other warm-season grasses, limpograss maintains its nutritional value with advancing maturity.

Despite high digestibility, however, limpograss crude protein concentration can be low. Crude protein tends to increase with nitrogen fertilization of limpograss, and protein is higher at the top of the canopy.

Organic-matter digestibility of young limpograss may be as high as 70 percent, but can drop to as low as 40 percent in mature, stockpiled grass. The protein concentration in young limpograss less than 6 weeks old will usually exceed 7 percent, especially in the cooler spring or fall periods. During the summer, the protein concentration of 6-week-old regrowth will fall below 7 percent even with fertilization of $60-80$ pounds of nitrogen $(\mathrm{N})$ per acre. Stockpiled Floralta or Bigalta 12 - 16 weeks old may only have a protein concentration of 3 percent, but digestibility and palatability are relatively high. With protein supplementation, mature pregnant cows that are fed limpograss can be maintained and, in some situations, their body condition can be improved.

Tissue phosphorus and potassium concentrations of limpograss may range from $0.15-0.30$ percent for phosphorus and from $0.8-1.0$ percent for potassium. 


\section{Animal Performance}

Studies on continuously grazed (continuous stocking) limpograss pastures have reported average daily gains (ADG) of crossbred yearling heifers that range from $0.5-1.4 \mathrm{lb}$ per day. In cow-calf operations, cows can gain, on average, 1 unit of body condition score when grazing limpograss pastures during the summer. However, cows grazing limpograss during the winter will loose body condition if their diet is not supplemented properly.

\section{Planting}

Limpograss seed production is low, but the long, decumbent stems root readily at the nodes, making vegetative propagation through sprigging an accepted commercial practice.

In Florida it is best to establish limpograss during the rainy season (June-August). However, if irrigation is available to provide moisture regularly, limpograss can be planted as early as April-May. In some South Florida areas, limpograss plantings can be made through August and even later. Warmer winters in South Florida can also make it possible for stockpiled grass to overwinter without freezing, allowing for spring planting using this material.

If targeting establishment with only summer rains, seedbed preparation should be in April-May. Control weeds first, and take care of soil needs next. Many weeds can be controlled through cultivation prior to planting. Herbicide treatment is recommended on land infested with broadleaf weeds. Use Banvel herbicide. Do not use 2,4-D or Weedmaster (contains 2,4-D) since limpograss is sensitive to this herbicide. For other herbicide recommendations, see EDIS Publication SSAGR08, Weed Management in Pastures and Rangeland2009 (http://edis.ifas.ufl.edu/WG006).

When preparing a field for planting, test the soil to determine plant nutrients present in the soil, as well as the degree of acidity or alkalinity, and, therefore, the lime needs of the soil. The results of a soil test will provide all information necessary for fertilizer recommendations.
Liming is needed only when soil $\mathrm{pH}$ is below the recommended target $\mathrm{pH}$ of 5.5. Lime should be applied two to six months before planting to allow adequate time for the soil to react with the lime and alter $\mathrm{pH}$. Do not apply fertilizer at the same time as lime because the fertilizer will not be available for the plants for use.

Instead, fertilizer -- nitrogen $(\mathrm{N})$, phosphorus $(\mathrm{P})$, and potassium $(\mathrm{K})$-- should be applied after planting, when the grass has sprouted and started to grow. After plants have emerged, apply $30 \mathrm{lb}$ N/acre, all of the soil-test-recommended $\mathrm{P}_{2} \mathrm{O}_{5}$ and half of the recommended $\mathrm{K}_{2} \mathrm{O}$. Apply the remaining $\mathrm{K}_{2} \mathrm{O}$ and 70 lb N/acre 30 - 50 days later.

Stems tops and stolons that have been recently cut should be spread in the prepared seedbed and covered to a 2-3 inch depth using a disk harrow or similar implement. A cultipacker (or similar equipment) should follow the disking operation in order to produce a smoother pasture, establish soil capillarity, and insure rooting with good soil contact. The amount of planting material needed will range from 1000 - $2000 \mathrm{lb} /$ acre. Use a minimum of 1,000 pounds/acre of planting material on newly prepared native land. Higher rates of 1,500 - 2,000 pounds/acre of planting material may be required when renovating fields used for pasture previously, but which have become infested with other grasses and broadleaf weeds.

Utilization by grazing or mowing should be delayed until limpograss is well established. To give the grass additional time to establish before being subjected to grazing, take the first harvest as hay.

Before planting aeschynomene, carpon desmodium, or some other summer legume at the same time the limpograss is planted, try to determine whether broadleaf weeds will be a problem as the use of residual herbicide to control weeds will kill the legumes. Additionally, reduce the normal planting rate for the legume to avoid excessive competition with the grass. 


\section{Management}

\section{A. Fertilizer and Liming Recommendations}

Liming is needed only when soil $\mathrm{pH}$ is below the recommended target $\mathrm{pH}$ of 5.5. Lime as needed to maintain a soil $\mathrm{pH}$ of 5.5 .

\section{Pastures}

For grazed, established stands, apply $60 \mathrm{lb}$ $\mathrm{N} /$ acre and all of the soil-test recommended $\mathrm{P}_{2} \mathrm{O}_{5}$ and $\mathrm{K}_{2} \mathrm{O}$ levels in late winter or early spring. Apply an additional $60 \mathrm{lb}$ N/acre in late summer or early fall. For a minimum fertilization alternative, ignore the $\mathrm{P}$ and $\mathrm{K}$ recommendation and apply only $60 \mathrm{lb}$ N/acre per year.

\section{Hay, Silage, or Green Chop}

Apply $80 \mathrm{lb}$ N/acre and all of the recommended $\mathrm{P}_{2} \mathrm{O}_{5}$ and $\mathrm{K}_{2} \mathrm{O}$ levels in late winter or early spring. Apply an additional $80 \mathrm{lb} \mathrm{N}$ and $40 \mathrm{lb} \mathrm{K}_{2} \mathrm{O} / \mathrm{acre}$ after each cutting, except the last in the fall. Include $20 \mathrm{lb}$ of $\mathrm{P}_{2} \mathrm{O}_{5}$ in the supplemental fertilizer if the soil tested low or medium in $\mathrm{P}$.

\section{B. Weed Control}

If limpograss pastures are closely grazed or overgrazed, opportunistic weed plants may invade limpograss stands and pastures. Some grassy weeds include common bermudagrass and vaseygrass. Proper grazing or stubble height will keep these grassy weeds from encroaching. Leaving a conservative stubble height (10 - 12 inches) will reduce vaseygrass population without allowing major infestation by common bermudagrass.

Broadleaf weeds can be controlled with chemical herbicides. However, as indicated in the establishment section, do not use 2,4-D (there are several brands) or 2,4-D mixtures, such as Weedmaster (2,4-D + dicamba) because these will injure or kill limpograss. Limpograss has shown more tolerance to dicamba (brand examples are Banvel, Clarity or Vanquish) than to 2,4-D. Therefore, dicamba is recommended for control of broad-leaf weeds in limpograss.

\section{Grazing Management}

Limpograss should be grazed to a stubble height of 10 - 12 inches or higher under rotational grazing (rotational stocking) or to 12 - 16 inches under continuous grazing (continuous stocking). Do not graze the grass to the ground level except during the winter. However, animals should be removed as soon as this happens, and they should not be returned to the area until the grass has grown to a height of 12 inches or more. Then graze, but take only one-half of the top growth.

As the warm season progresses, try not to let the grass grow taller than 18 - 24 inches. Extremely tall grass results in waste through trampling. Trampling causes a buildup of mulch, which increases the possibility of insect damage from spittlebug and chinchbug.

Rotational grazing is recommended. Rotational grazing will increase total production from the pastures as compared to continuous grazing and should increase the persistence of limpograss.

\section{Supplementation on Pasture}

Limpograss quality decreases as the grass matures. However, 8-to-10-week-old limpograss regrowth has a higher digestibility (TDN) than bahiagrass of the same maturity. The crude protein of limpograss will decline as it matures, and low protein often limits forage intake and digestibility (Table 1).

Limpograss stems and leaves have similar digestibility, but the crude protein concentration in the stems is about one-half of the crude protein concentration in the leaves. Consequently, the relative leaf-to-stem ratio consumed by the grazing animal will affect the animal's need for protein supplementation.

The TDN-to-crude protein ratio (TDN:CP) is a measure of the balance between digestible energy (TDN) and protein. In forages with TDN:CP ratios of 7 or below, added protein supplements usually do not result in large improvements in animal performance. In forages with TDN:CP ratios above 7 , added protein supplements usually result in improvements in forage intake and cattle gains. Ratios above 7 are common in limpograss 
Several strategies -- including protein supplementation, growing limpograss with a legume, nitrogen fertilization, and managing grazing for consumption of mostly leaves -- have been successful in avoiding protein deficiencies in cattle grazing limpograss. Feeding growing cattle that were grazing limpograss in a six-pasture rotational grazing program (five weeks between grazings) $0.25-0.50 \mathrm{lb} / \mathrm{day}$ per animal of crude protein from a urea-based supplement improved animal gains 0.4 - 0.7 lb/day.

Interseeding limpograss with aeschynomene also improved animal gains $0.4-0.5 \mathrm{lb} / \mathrm{day}$, nearly as much as protein supplements. Higher nitrogen fertilization rates (130 lb N/acre compared to $45 \mathrm{lb}$ N/acre) improved forage crude protein concentration and gains of growing cattle. However, some additional improvement in gain $(0.2 \mathrm{lb} /$ day $)$ was found when a urea-based supplement was fed at the higher level of nitrogen fertilization.

In contrast to these trials, when growing cattle were rotationally grazed on limpograss pasture at a stocking rate allowing a significant amount of residual forage during the summer, protein supplements did not improve gains. Presumably cattle were consuming mostly leaves that were higher in protein.

Under continuous grazing, maintaining a pasture height of about 16 inches resulted in better animal gain and stand persistence than maintaining a height of 8 or 24 inches. Invasion by common bermudagrass was a major problem when the pasture was grazed throughout the warm season to 8 inches.

Protein supplements are recommended for cattle grazing stockpiled limpograss. The quantity of supplemental protein needed increases as the plant is defoliated, and a higher proportion of stems are consumed.

In South Florida, replacement heifers grazing stockpiled limpograss and receiving $0,2.5$, or 5.0 $\mathrm{lb} / \mathrm{head} / \mathrm{d}$ of cottonseed meal gained $0.7,1.3$, and 1.7 $\mathrm{lb} / \mathrm{d}$, respectively. Heifers grazing stockpiled limpograss and grazing annual ryegrass three times per week had the same performance as heifers receiving $5 \mathrm{lb} / \mathrm{head} / \mathrm{d}$ of cottonseed meal.

\section{E. Association with Legumes}

A couple of legumes are adapted to the high-moisture conditions in which limpograss grows: aeschynomene during the warm season and white clover during the cool season.

Aeschynomene grown in limpograss pastures provides much-needed protein from July through September and has produced significant increases in animal gain. Aeschynomene production varies from year to year. In those years with above-average spring rainfall, production will be better than other years. Spring rainfall allows the aeschynomene to germinate and start growing earlier.

In South Florida, if soil moisture is good during the cool season, white clover can be overseeded in limpograss pastures in the fall if the pastures are not stockpiled during the fall.

\section{Utilization}

\section{A. Stockpiling}

Stockpiling allows forage grown during peak periods to be utilized during periods of deficit. In Florida, the practice of stockpiling leaves a standing hay crop in the fall for use later, when there is not much grass growth. Limpograss is used in stockpiling because the digestibility of limpograss remains relatively high as the plants matures, compared to the digestibility of other warm-season species.

Stockpiling, with significant growth in September and October, is usually achieved by removing cattle in mid-August from the area where grass is to be stockpiled, followed by fertilization. (Not much growth will occur if the grass is fertilized in September or October.)

The nutritive value of stockpiled limpograss is highly dependent on management practices and climatic conditions. However, an average 3 percent $\mathrm{CP}$ and 50 percent TDN is typical for stockpiled limpograss. For this reason, animals grazing the stockpiled grass will need supplementation to maintain adequate nutritional status.

Do not stockpile grass during June, July, and early August. By November, the grass that grew 
during this period will be very mature, and cattle may, therefore, refuse to eat it. Stockpiling during the summer months also encourages the buildup of spittlebugs, which results in damage to the grass.

\section{B. Hay or Silage}

Limpograss has been successfully conserved as silage by ranchers and dairymen, who like the excellent silage the grass makes. This silage is characterized by a 'sweet' fragrance that remains preserved even up to a couple of years if stored properly.

The maturity stage to harvest limpograss is between 4 and 6 weeks old and no more than 6 weeks old. However, ammoniation can be used to increase feeding value if the grass is more than 6 weeks old or has been rain damaged. Because of the thicker limpograss stems, limpograss for hay dries slower than bermudagrass; a conditioner can be used to crush the stems and speed up the drying time. Growers have been able to successfully fertilize and harvest on a five-to-six-week schedule throughout the growing season.

\section{Insects and Plant Diseases}

Spittlebugs may become a problem in limpograss if the grass is left ungrazed, and a thatch accumulates. Mowing or burning the excess grass growth or pasture thatch is the management-control option of choice.

Occasionally, damage from chinchbugs (Blissus insularis) and caterpillars -- such as fall army worms (Spodoptera) and loopers (Moscis) -- have been reported. Drought stressed plants may be attacked by a blight characterized by browning of the new growth. This condition has been diagnosed as 'Take-all Root Rot' (Gaeumannomyces graminis), a condition that disappears when the plant tissue is removed by cutting or burning. Sting nematodes can be a significant pest on deep, well drained sands, so planting is not recommended on these areas.

\section{Summary}

- Limpograss is a warm-season plant adapted to areas of high moisture that are poorly drained. None of the released cultivars are adapted to Florida's deep sandy soils.

- Limpograss is high in digestibility, but $\mathrm{CP}$ concentration may be low.

- Floralta is the recommended cultivar for planting because it is more tolerant than Bigalta to heavy grazing.

- Compared to bahiagrass, limpograss has superior late-fall and early-spring production, especially in South Florida.

- Limpograss is highly productive when well fertilized and competes well with broadleaf and grassy weeds as long as stubble height is not overly reduced by grazing or cutting.

- Mature limpograss is more digestible than many other grasses are at maturity, but crude protein can be low in accumulated or stockpiled limpograss. As a result, animals fed stockpiled limpograss need protein supplementation.

- Floralta and Bigalta are difficult to dry for hay at advanced stages of growth due to the high yield, large stems, and moist soils where they grow.

\section{Literature Cited}

Newman, Y. C., Sollenberger, L. E., Kunkle, W. E., and Chambliss, C. G. 2002. Canopy height and nitrogen supplementation effects on performance of heifers grazing limpograss. Agron. J. 94:1375-1380

Sellers, B.A. and Ferrell, J.A. 2009. Weed Management in Pastures and Rangeland - 2009. EDIS Publication SSAGR08, http://edis.ifas.ufl.edu/wg006. Department of Agronomy, Institute of Food and Agricultural Sciences, University of Florida, Gainesville, FL. 
Sollenberger, L. E., Ocumpaugh, W. R. Euclides,

V. P. B., Moore, J. E., Quesenberry, K. H, and Jones

Jr., C. S. 1988. Animal performance on continuously

stocked Pensacola bahiagrass and Floralta

limpograss pastures. J. Prod. Agric. 1:216-220.

\section{Additional Information}

Limpograss. Forages of Florida Web site -http://agronomy.ifas.ufl.edu/ForagesofFlorida/ detail.php?sp=Limpograss\&type $=\mathrm{G}$ 
Table 1. Pasture Nutritive Value (Digestibility and Crude Protein) and Herbage Mass of 'Pensacola' Bahiagrass and 'Floralta' Limpograss Pastures during the Grazing Season.

\begin{tabular}{||l|c|c|c|c|c|c||}
\hline & \multicolumn{2}{|c|}{$\%$ Digestibility } & \multicolumn{2}{c||}{ \% Crude Protein } & \multicolumn{2}{c||}{$\begin{array}{c}\text { Herbage Mass } \\
\text { (b DM/acre) }\end{array}$} \\
\hline & Bahiagrass & Limpograss & Bahiagrass & Limpgrass & Bahiagrass & Limpograss \\
\hline July & 50 & 60 & 7.2 & 5.0 & 3,000 & 5,000 \\
\hline August & 45 & 55 & 6.1 & 3.5 & 3,000 & 6,810 \\
\hline September & 43 & 53 & 9.0 & 4.2 & 2,810 & 6,610 \\
\hline October & 40 & 49 & 7.9 & 4.2 & 2,600 & 5,800 \\
\hline November & 37 & 48 & 7.5 & 4.8 & 2,200 & 4,800 \\
\hline Data from Sollenberger et. al. 1988, University of Florida. \\
\hline
\end{tabular}

Table 2. Average Daily Gain (ADG) of Crossbred Heifers Continuously Grazing Limpograss to Different Pasture Heights with or without Supplement.

\begin{tabular}{|c|c|c|}
\hline \multirow[t]{2}{*}{ Pasture Height } & \multicolumn{2}{|c|}{ ADG } \\
\hline & Non-Supplemented & Supplemented $^{a}$ \\
\hline Inches & \multicolumn{2}{|c|}{ 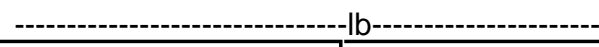 } \\
\hline 8 & 1.0 & 1.4 \\
\hline 16 & 1.4 & 1.2 \\
\hline 24 & 0.7 & 1.2 \\
\hline \multicolumn{3}{|c|}{$\begin{array}{l}\text { a Supplement consisted of a } 44 \text { percent CP corn-urea mixture } \\
\text { fed at a rate of } 1.4 \mathrm{lb} / \text { day. } \\
\text { Data from Newman et al., 2002. University of Florida }\end{array}$} \\
\hline
\end{tabular}

